\title{
Using hydrologic measurements to investigate free-phase gas ebullition in a Maine peatland, USA
}

\author{
C. E. Bon ${ }^{1}$, A. S. Reeve ${ }^{1}$, L. Slater ${ }^{2}$, and X. Comas ${ }^{3}$ \\ ${ }^{1}$ Department of Earth \& Climate Sciences, University of Maine, Orono, ME 04469-5790, USA \\ ${ }^{2}$ Department of Earth \& Environmental Sciences, Rutgers University, Newark, NJ 07102, USA \\ ${ }^{3}$ Department of Geosciences, Florida Atlantic University, Davie, Florida 33314, USA
}

Correspondence to: C. E. Bon (christiaan.bon@maine.edu)

Received: 20 May 2013 - Published in Hydrol. Earth Syst. Sci. Discuss.: 24 July 2013

Revised: 27 January 2014 - Accepted: 3 February 2014 - Published: 10 March 2014

\begin{abstract}
Northern peatlands cover more than 350 million ha and are an important source of methane $\left(\mathrm{CH}_{4}\right)$ and other biogenic gases contributing to climate change. Free-phase gas (FPG) accumulation and episodic release has recently been recognized as an important mechanism for biogenic gas flux from peatlands. It is likely that gas production and groundwater flow are interconnected in peatlands: groundwater flow influences gas production by regulating geochemical conditions and nutrient supply available for methanogenesis, while FPG influences groundwater flow through a reduction in peat permeability and by creating excess pore water pressures. Water samples collected from three well sites at Caribou Bog, Maine, show substantial dissolved $\mathrm{CH}_{4}\left(5-16 \mathrm{mg} \mathrm{L}^{-1}\right)$ in peat waters below $2 \mathrm{~m}$ depth and an increase in concentrations with depth. This suggests production and storage of $\mathrm{CH}_{4}$ in deep peat that may be episodically released as FPG. Two min increment pressure transducer data reveal approximately $5 \mathrm{~cm}$ fluctuations in hydraulic head from both deep and shallow peat that are believed to be indicative of FPG release. FPG release persists up to $24 \mathrm{~h}$ during decreasing atmospheric pressure and a rising water table. Preferential flow is seen towards an area of relatively lower hydraulic head associated with the esker and pool system. Increased $\mathrm{CH}_{4}$ concentrations are also found at the depth of the esker crest, suggesting that the high permeability esker is acting as a conduit for groundwater flow, driving a downward transport of labile carbon, resulting in higher rates of $\mathrm{CH}_{4}$ production.
\end{abstract}

\section{Introduction}

\subsection{Significance}

Northern peatlands cover $\sim 10 \%$ of land north of $45^{\circ} \mathrm{N}(3 \%$ of Earth's surface) and contain about one-third of all soil carbon (Gorham, 1991; Wigley and Schimel, 2000; Rydin et al., 2006). Although it is commonly assumed that this large carbon sink will mitigate climate change as increased precipitation decreases peat decomposition, these peatlands are also an important source of methane $\left(\mathrm{CH}_{4}\right)$ and other biogenic gases that contribute to greenhouse gases in the atmosphere (Khalil, 2000). Net carbon accumulation rates in northern peatlands have been modeled at $76 \mathrm{TgC} \mathrm{yr}^{-1}$ and rates of $\mathrm{CH}_{4}$ have been modeled at $46 \mathrm{Tg} \mathrm{CH}_{4}-\mathrm{C} \mathrm{yr}^{-1}$, contributing 5-10\% of total terrestrial $\mathrm{CH}_{4}$ flux to the atmosphere (Gorham, 1991). These numbers will likely need revision with the emerging importance of free-phase gas (FPG) emissions from peatlands. Results from climate models disagree on the response of peatlands to climate change; some models show increased $\mathrm{CH}_{4}$ emissions due to an increased breakdown of peat, while others show an accelerated carbon storage in peatlands due to a warmer and wetter climate (Walter et al., 2001). A major contributor to the current uncertainty regarding how carbon cycling in peatlands will respond to climate warming is our incomplete understanding of the production, storage and emission of FPG, a previously underappreciated pathway of $\mathrm{CH}_{4}$ and carbon dioxide $\left(\mathrm{CO}_{2}\right)$ emissions to the atmosphere. The two major constituent FPGs produced in the peatland subsurface are $\mathrm{CO}_{2}$ and, the focus of this study, $\mathrm{CH}_{4}$ (Tokida et al., 2007b). 
"Deep Peat" Model

\section{"Shallow Peat" Model}

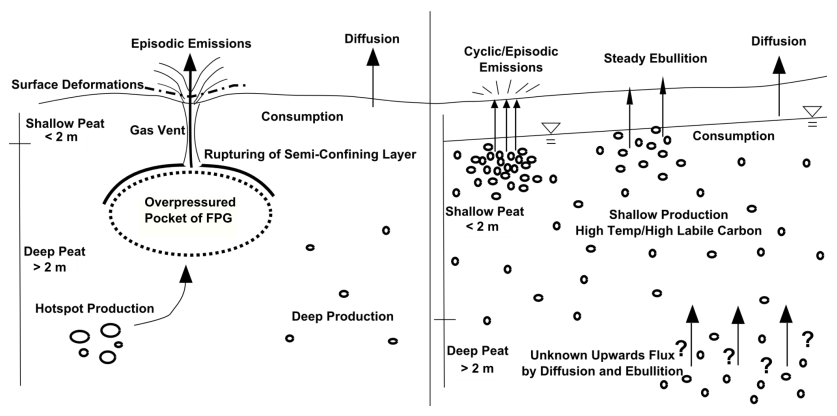

Fig. 1. Two competing models for ebullition of $\mathrm{CH}_{4}$ from northern peatlands. Left: "deep peat" ebullition model modified from Glaser et al. (2004). Right: "shallow peat" ebullition model modified from Coulthard et al. (2009). Notice the unknown upward flux of $\mathrm{CH}_{4}$ from deeper peat that was a "call for further research". This study is a direct response to this call for research.

\subsection{Free-phase gas in northern peatlands}

It is likely that gas production and groundwater flow are interconnected in peatlands: groundwater flow influences gas production by regulating geochemical conditions and nutrient supply available for methanogenesis, while FPG influences groundwater flow through a reduction in peat permeability and excess pore fluid pressures (Baird and Waldron, 2003). Two models have been proposed for the production, storage, and emission of $\mathrm{CH}_{4}$ and other FPGs with respect to the hydraulics of a peatland. The first has been called the "deep peat model" and was proposed based on field investigations of the Lake Agassiz Peatlands, MN (Glaser et al., 2004). In this model, FPG is produced in shallow and deep peat, and gas that is produced in deep peat is trapped in semiconfining layers that episodically rupture due to changes in atmospheric pressure (Fig. 1). The sporadic rupturing of these layers is also accompanied by deformations of the peatland surface. The deep production model includes diffusion of shallow peat $\mathrm{CH}_{4}$ to the atmosphere and production at depth due to a downward transport of labile carbon. The second model has been called the "shallow peat model" and was proposed after numerous laboratory studies (Coulthard et al., 2009). The shallow peat model showed steady ebullition, diffusion, and episodic ebullition occurring from the upper layers of peat (Fig. 1). This is due to higher FPG production rates associated with higher temperatures and a higher supply of labile carbon that interacts with the water table and causes nucleation of FPG bubbles. These studies did include an unknown upward flux from deeper peat $(>2 \mathrm{~m})$. Little was known about FPG production and flux from deeper peat, and this was to "act as stimulus for further research" (Coulthard et al., 2009).

FPG and dissolved gases are transferred from peatlands to the atmosphere in three main ways: diffusion, ebullition, and plant-mediated transport. Diffusion occurs due to a $\mathrm{CH}_{4}$ gradient between the peat pore fluids and the atmosphere. Diffusion is slow compared to the other two methods of transport (Lai, 2009). Diffusion also occurs from roots in the anaerobic zone through aerenchyma in vascular plants that act as conduits for $\mathrm{CH}_{4}$ escaping to the atmosphere (Joabsson and Christensen, 2001). Free-phase gas forms (the first step in ebullition) when differences between the partial pressures of dissolved gas in peat pore waters and atmospheric pressure trigger dissolved gas to form bubbles (Chanton and Whiting, 1996). This FPG is much more mobile than dissolved gas. Changes in atmospheric pressure cause changes in FPG bubble size, forcing the buoyant bubbles to move up the saturated peat column (Glaser et al., 2004; Tokida et al., 2007b). The bubbles do not escape to the atmosphere immediately but must reach a pressure threshold that triggers an ebullition event. Ebullition events have been known to occur in response to a rising water table as the buoyancy of formed bubbles causes them to propagate upwards with the rising water table (Coulthard et al., 2009). Decreases in atmospheric pressure were thought to cause an increase in pressure difference between pore fluids and the atmosphere causing freephase gas bubbles to release to the atmosphere (Tokida et al., 2007b). Ebullition events have also been known to occur as $4-12 \mathrm{~h}$ events as peat depressuring cycles (Glaser et al., 2004). Ebullition accounts for 50-60\% of total $\mathrm{CH}_{4}$ flux from northern peatlands and is a major mode of gas release from deeper peat (Tokida et al., 2007a) stressing the importance of further understanding $\mathrm{CH}_{4}$ production and release at greater depth.

\subsection{Methane production and consumption}

$\mathrm{CH}_{4}$, a major component of FPG and a potent greenhouse gas, is produced by microorganisms in two major processes in peat: greater than two-thirds is produced through the splitting of acetate, from partially decomposed organic matter, and the remaining third through the reduction of $\mathrm{CO}_{2}$ with $\mathrm{H}_{2}$ (Conrad, 1999; Whalen, 2005). These two processes occur due to the interaction of methanogens and organic matter in the absence of oxygen. Acetotrophic methanogens produce $\mathrm{CH}_{4}$ and carbon dioxide from acetate produced from the fermentation of polysaccharides (Lai, 2009):

$\mathrm{CH}_{3} \mathrm{COO}^{-}+\mathrm{H}^{+} \rightarrow \mathrm{CH}_{4}+\mathrm{CO}_{2}$.

Hydrogenotrophic methanogens produce water and $\mathrm{CH}_{4}$ through a reduction of $\mathrm{CO}_{2}$ by using $\mathrm{H}_{2}$, also created by fermenters of polysaccharides, as an electron donor (Lai, 2009):

$4 \mathrm{H}_{2}+\mathrm{CO}_{2} \rightarrow \mathrm{CH}_{4}+2 \mathrm{H}_{2} \mathrm{O}$.

The breakdown of acetate is favored in the upper layers of peat where there is abundant labile carbon and there are higher summer temperatures, while reduction of $\mathrm{CO}_{2}$ is favored in more recalcitrant, deeper peat (Hornibrook et al., 
1997). The abundant $\mathrm{CO}_{2}$ at depth and presence of microbial communities could mean that substantial production of $\mathrm{CH}_{4}$ is possible in peat greater than $1 \mathrm{~m}$ depth and would be even greater where downward transport of labile carbon is present. Saturation of $\mathrm{CH}_{4}$ in water at standard pressure and room temperature is $22.7 \mathrm{mg} \mathrm{L}^{-1}$ (Wiesenburg and Guinasso, 1979), but bubbles have been found to form at concentrations far below this saturation concentration (Baird et al., 2004).

$\mathrm{CH}_{4}$ can also be consumed by methanotrophs in anaerobic peat layers (Lai, 2009). Methanotrophs consume reduced single-carbon compounds and assimilate formaldehyde for energy (Hanson and Hanson, 1996). The highest rates of methanotrophic activity occur near the water table in the upper peat layers, where oxygen and $\mathrm{CH}_{4}$ occur in optimal proportions (Dedysh, 2002). Methanotrophic activity can limit the amount of $\mathrm{CH}_{4}$ emitted to the atmosphere from peatlands by oxidizing large amounts of $\mathrm{CH}_{4}$ produced in oxygen-depleted zones (Sundh et al., 1994; Lai, 2009). Methanotrophic activity is limited in deeper peat, where oxygen is depleted.

$\mathrm{CH}_{4}$ in deep peat has been shown to be radiocarbon enriched compared to the surrounding peat, suggesting anaerobic respiration that is supported by a downward transport of younger dissolved organic carbon (Aravena et al., 1993; Charman et al., 1994; Chanton et al., 1995). Chanton et al. (1995) estimated that $\mathrm{CH}_{4}$ in pore waters contained as much as $25 \%$ modern carbon at $2.5 \mathrm{~m}$ depths. This suggests that enhancement of microbial respiration and $\mathrm{CH}_{4}$ production is possible with increased downward transport of labile carbon.

Limited research has been performed to determine the production and transport of $\mathrm{CH}_{4}$ at depths greater than $1 \mathrm{~m}$ (Romanowicz et al., 1995). There has also been some controversy over the abundance of FPG in the catotelm and the significance of that gas in global greenhouse gas emissions (Glaser et al., 2004). This study will quantify the $\mathrm{CH}_{4}$ concentrations in water samples from different peat depths ranging from 0.5 to $7 \mathrm{~m}$ and examine possible mechanisms for variability of these concentrations and the release of FPG from depth. We hypothesize that at Caribou Bog, ME, (a) short-term increases in pressure gradients between pore fluids and the atmosphere episodically trigger FPG release, (b) that episodic ebullition events will produce rapid changes in hydraulic head, and (c) a well-documented esker acts as a highly permeable unit that influences flow patterns, driving a downward transport of labile carbon, and thus increases $\mathrm{CH}_{4}$ production at depth.

\section{Study site}

Major projects investigating peatland hydrology and development have focused on the largest peat basins in North America, such as the Hudson Bay Lowlands and glacial Lake

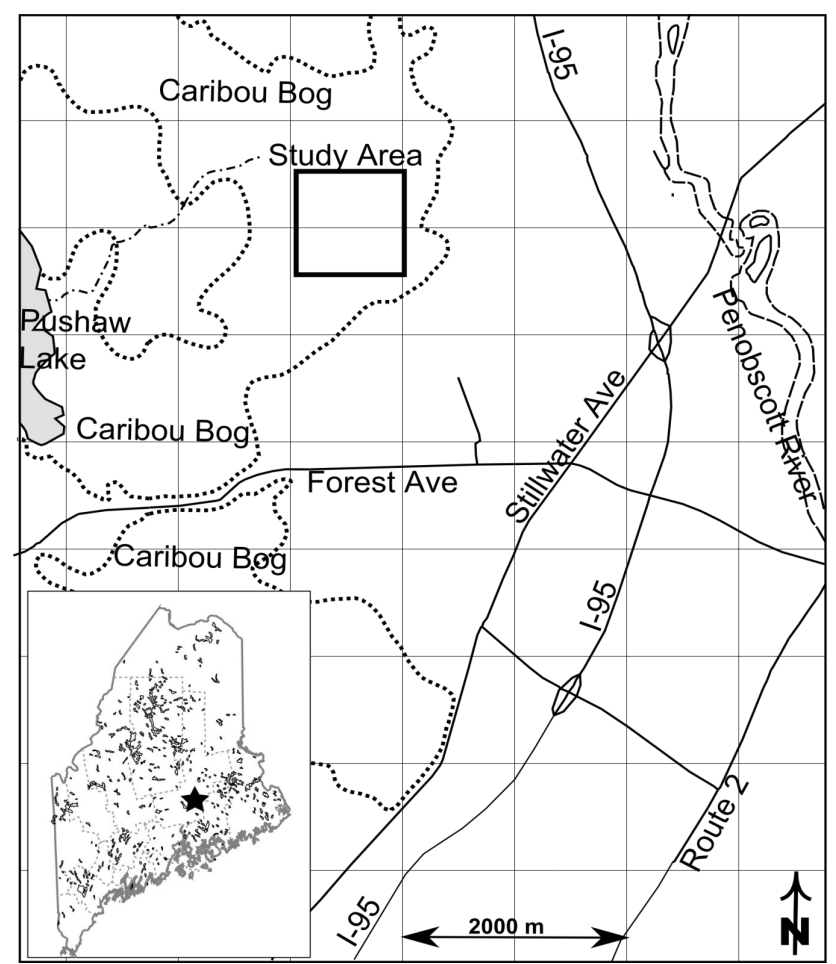

Fig. 2. Map of central and southern portion of Caribou Bog (outlined by dashed line), a multiunit peatland, with study area in the central unit highlighted by the black box. The study area is shown enlarged in Fig. 10.

Agassiz Peatlands (Sjörs, 1959; Glaser et al., 1981; Siegel, 1983). These peatlands are in remote locations and detailed hydrologic studies are expensive. Though the study site in Caribou Bog, ME, USA (Fig. 2), is a much smaller and more accessible peatland, the processes controlling $\mathrm{CH}_{4}$ production and emission are similar to those in the large peat basins of North America (Comas et al., 2008; Parsekian et al., 2010), suggesting that work performed on Maine's peatlands may be transferable to the larger northern peatland systems.

Caribou Bog, $24 \mathrm{~km}$ northeast of Bangor, ME, is a multiunit peatland composed of several raised bog complexes with a well-developed pool system in the central unit (Davis and Anderson, 1999). This is a comparatively large peatland by Maine standards, spanning $27 \mathrm{~km}$ around Pushaw Lake to the west and covering approximately 2200 ha (Davis and Anderson, 1999). The study site comprises 30 ha of the central unit in the eastern part of Caribou Bog (Fig. 2). Caribou Bog is an eccentric bog exhibiting a dome-shaped surface. Eccentric bogs occur on gently sloping terrain with poor drainage (Davis and Anderson, 2001). The peat surface is bounded by mineral uplands at the top of the slope and terminates as a kidney-shaped fen at the base (Davis and Anderson, 2001). At Caribou Bog, the ombrotrophic surface contains pools near the center and has alternating ridges and troughs dispersing from this pool system (Davis and Anderson, 2001). 
Other studies have shown the importance of subsurface landforms in regulating flow and pool formation in peatlands (e.g., Lowry et al., 2009). Maine's glacial history has provided diverse landforms below the peat in Caribou Bog that may regulate groundwater flow. Electrical resistivity (ER) data show $\sim 10 \mathrm{~m}$ of till, glaciomarine sediment, and lake sediment and up to $15 \mathrm{~m}$ of well-developed peat, all overlying bedrock (Comas et al., 2004). Further ground-penetrating radar (GPR) and ER studies concluded that a beaded esker deposit exists below the peat surface at the easternmost side of the pool system and follows a general $\mathrm{N}-\mathrm{S}$ direction (Fig. 10) (Comas et al., 2011). The esker, along with other eskers in the area, is most likely part of the Katahdin system left as the result of water-filled tunnels along the southern margins of the ice sheet as it retreated during the last deglaciation about $12700 \mathrm{yr}$ ago (Borns, 1963). GPR studies have shown a beaded esker deposit under the easternmost portion of the pool system next to site (ii). Esker crests are about $3 \mathrm{~m}$ below the bog surface (Comas et al., 2004), with mineral soil (glaciomarine and lake sediment) overlapping its sides. The esker material is highly permeable, with hydraulic conductivity values much greater than the surrounding peat (Reeve et al., 2009). This highly permeable lens may act as a conduit for flow out of the peatland causing a downward flow and a downward transport of labile carbon that drives higher rates of methanogenesis.

\section{Methods}

\subsection{Geo-referenced water level and pore fluid pressure data}

Clusters of PVC monitoring wells $(2.54 \mathrm{~cm}$-diameter flushthreaded PVC, $30 \mathrm{~cm}$ machine-slotted $(0.05 \mathrm{~cm})$ screen) were manually installed in 9 locations of Caribou Bog with a horizontal spacing of $\sim 100 \mathrm{~m}$ (Fig. 10). Well sites were chosen to create an array of wells to easily calculate flow directions in the central unit and by accessibility. Each well was inserted into the peat manually with a slide hammer and hit until the desired peat depth was reached. The first well was installed down to the mineral soil with the following monitoring wells installed at 1 to $2 \mathrm{~m}$ intervals from the first to create clusters of 6 to 8 wells. Two wood boards $(3.81 \mathrm{~cm} \times 6.35 \mathrm{~cm} \times 121.92 \mathrm{~cm})$ were clamped together and eight $2.54 \mathrm{~cm}$-diameter holes were drilled through the boards with the hole centered along the surface of the intersecting boards. Nine bolts were then used to tightly clamp the wooden boards around the wells. The deepest wells were positioned at the ends of each well cluster and typically extended into the mineral soil. The frame prevented individual movement of a well during peat deformation. Excess PVC was cut from all the wells using a carpenter level and saw. Height measurements were taken from the bog surface to the board and the top of wells for future use with global position- ing system (GPS) data and to monitor movement of wells over time. Well screens were cleaned after installation by scrubbing the inside of each well with a bottle brush attached to a $1.3 \mathrm{~cm}$ threaded PVC pipe and then purged with a hand pump to remove debris from the well. To reduce the importance of well storage and its impact on monitoring well response, $2.1 \mathrm{~cm}$-diameter PVC pipe was inserted in each monitoring well from the surface to about $1 \mathrm{~m}$ below the water level. This reduced the cross-sectional area in wells by $33 \%$ while still allowing direct measurement of water levels. The wells were sealed with a vented cap, and a short boardwalk was constructed adjacent to each well to mitigate the influence of a person's weight during water level measurements.

Well clusters were surveyed using a Trimble NetR9 GPS dual-frequency receiver with zephyr antenna that recorded data at $10 \mathrm{~s}$ intervals. The antenna was positioned on top of the wells, and the receiver collected data for about an hour to ensure high accuracy. Height measurements were taken from the antenna to the top of each well, and Topcon Link postprocessing software was used to obtain a coordinate location and height (above sea level $\pm 5 \mathrm{~cm}$ ) of each well cluster. This location and height were used as a reference for all calculations involving monitoring well depths and locations.

Solinst Barologger Gold was used to collect temporal atmospheric pressure data, while Solinst Junior non-vented data-logging pressure transducers were used to collect temporal hydraulic head and water temperature data for an entire year. Temporal hydraulic head and water temperature data were collected at three distinctly different locations in Caribou Bog in terms of peat thickness, vegetation, and landforms. The three sites (Fig. 10) are as follows:

i Shrub site: this site is downslope in the eastern section of the central unit with a peat thickness of $6.5 \mathrm{~m}$ and uniform shrub vegetation.

ii Pools and esker site: this site is towards the center of the primary pool complex where previous studies indicate extensive wood layers at depth, pronounced storage of deep gas and enhanced mixing between peat pore water and minerotrophic groundwater. An esker underlies the well cluster and may be responsible for enhanced mixing. Three meters of peat overlies the esker crest (Comas et al., 2011). A well cluster is located about $20 \mathrm{~m}$ north of the crest: peat thickness is estimated at $6 \mathrm{~m}$. A mix of Sphagnum moss and wooded heath vegetation cover this area.

iii Wooded heath and upland site: this site is to the west of the pools and characterized by the highest density of tall trees in Caribou Bog and proximity to a mineral upland. The mineral upland is approximately $50 \mathrm{~m}$ from the monitoring well cluster. Peat thickness is $\sim 5 \mathrm{~m}$. Vegetation is a mix of shrubs and evergreen trees. 
Data-logging pressure transducers were attached to the cap of each of the wells in the cluster by a string so that they could be retrieved to download data. Loggers were set to collect data at $2 \mathrm{~min}$ increments to examine fluctuations in hydraulic head that may be indicative of FPG release in the vicinity of the well. The logger data were compensated for atmospheric pressure with a barometric data-logging pressure transducer located at well site (ii).

Water level measurements were taken every two months while wells were unfrozen (May-November). Because electrical hand measurement devices could not be used due to low conductivity of peat pore water, a measuring tape attached to $2 \mathrm{~cm}$ plastic tubing was lowered down the piezometer while blowing into the tube. Bubbling was heard as the tube reached the water and a measurement was taken from the measuring tape $( \pm 0.1 \mathrm{~cm})$ that would indicate the distance between the water level and at the top of the piezometer. This was done multiple times to ensure an accurate reading and a stable water level. This measurement was subtracted from the surveyed elevation of each piezometer to give a water level with respect to sea level.

\subsection{Pressure data analysis}

The 2 min-interval hydrologic data sets from data-logging pressure transducers were compared with meteorological data and water table data to assess the forcing mechanisms (air pressure, water levels, temperature) of FPG emission. This provides a powerful diagnostic tool for assessing the importance of the forcing mechanisms on FPG storage and release following the methods of Rosenberry et al. (2003). Hydraulic head time series data were inspected to identify unusual fluctuations in hydraulic head data that differ from typical daily fluctuations in hydraulic head or differ from fluctuations due to data collection days when loggers were pulled from wells and the surrounding peat was disturbed by human activity. Unusual fluctuations could signal ebullition of gas from semi-confining layers around the well clusters or movement of bubbles past the well screen. These unusual fluctuations were overlain with atmospheric data to identify possible hydraulic drivers of FPG emission (i.e., drops in atmospheric pressure, changes in water table). Precipitation, air pressure, and air temperature data were collected at well site (ii) and at the University of Maine located $6.5 \mathrm{~km}$ to the east.

\subsection{Gas analysis}

\subsubsection{Headspace gas samples}

Some have questioned using monitoring wells for $\mathrm{CH}_{4}$ analysis because the wells disrupt the pressure regimes that are present and allow gas trapped in peat pore spaces to continually escape to the atmosphere (Rosenberry et al., 2003; Waddington et al., 2009). To assess if wells in Caribou Bog affect long-term gas storage within the peat column, five air

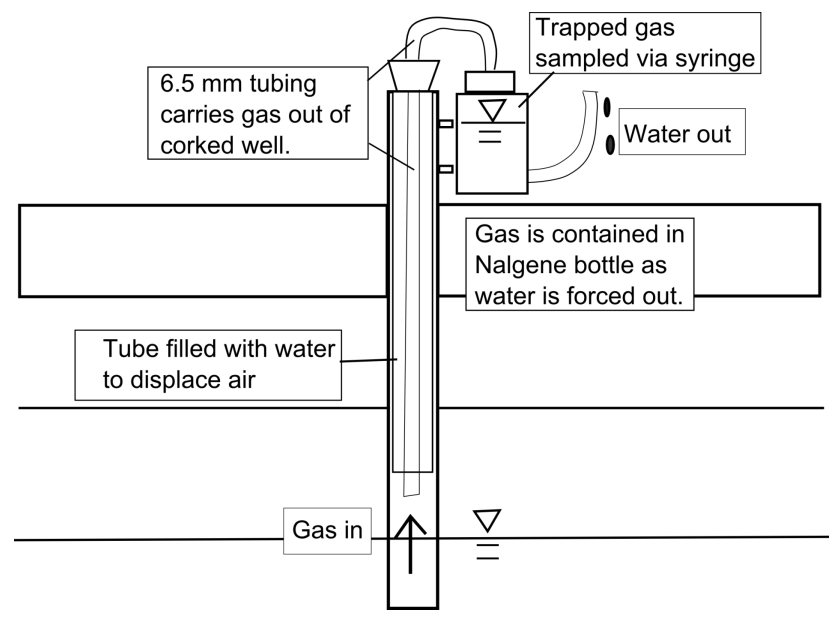

Fig. 3. Gas trap installed at one location to conclude if wells were conduits for gas release and change pressure regimes below the surface.

tight gas traps were installed at one location (Fig. 10) to determine concentrations of $\mathrm{CH}_{4}$ in well head space at depths of 7.5, 6.0, 4.5, 3.0, and $1.5 \mathrm{~m}$. This was done approximately seven months after the initial installation of the well cluster. To reduce headspace, the gas traps were fashioned with water-filled $2.54 \mathrm{~cm}$-diameter polyester film tubing that was heat-sealed on one end and attached to a cork that sealed the well on the other (Fig. 3). The tubing was positioned so that there was $10 \mathrm{~cm}$ of headspace above the current water level to allow for water level fluctuation. The polyester film tubing was then filled with water so that it filled to the diameter of the well and the well was sealed with a cork. A $6.35 \mathrm{~mm}$ clear vinyl tube - which ran from the headspace, alongside the polyester film tubing, and through the cork sealing the well - allowed headspace gases to flow out of the well and into a water-filled $50 \mathrm{~mL}$ Nalgene bottle. These bottles allowed water to flow out as the headspace gases moved in.

Gas samples were taken on 22 May and 24 May 2012. A 20-gauge syringe was used to obtain a $10 \mathrm{~mL}$ gas sample from the $6.35 \mathrm{~mm}$ vinyl tubing that carries gas from the well to the Nalgene bottle (Fig. 3). The sample was injected into a $10 \mathrm{~mL}$ glass vial that had been previously evacuated. That sample was then extracted and discarded to flush the vial. Another sample was then taken from the $6.35 \mathrm{~mm}$ tubing and $12.5 \mathrm{~mL}$ of sample was injected into the vial. Overpressurization of vials ensured that air that could oxidize methane would not be pulled into the vial.

\subsubsection{Water sampling and analysis}

Water samples were collected from sites (ii) and (iii) on 13 September 2012, and in duplicate from sites (i) and (ii) on 26 November 2012. The samples were refrigerated at $4^{\circ} \mathrm{C}$ and analyzed within 21 days of collection. Water samples were taken at each well depth following the methods of 
Romanowicz et al. (1995). Wells were purged via a vacuum hand pump until the well went dry. The well was allowed to partially or fully recover over a $60 \mathrm{~min}$ period. The well was then pumped again into an Erlenmeyer flask and then transferred carefully by pouring to a $10 \mathrm{~mL}$ glass vial so as not to agitate or create bubbles. Sample vials were capped and sealed with $20 \mathrm{~mm}$ PTFE-coated red rubber septa and $20 \mathrm{~mm}$ aluminum crimp seals so that no headspace was present. After collecting samples from many deeper wells, fine bubbles formed throughout the sample vial, indicating a change from aqueous to gas phase due to decreased pressure.

The samples were taken to the laboratory and analyzed for $\mathrm{CH}_{4}$ and $\mathrm{CO}_{2}$ using the dissolved gas analysis methods of Kampbell and Vandegrift (1998). The sample vials were prepared for analysis by replacing $8 \mathrm{~mL}$ water sample with nitrogen gas using two 20-gauge syringes. One syringe was filled with nitrogen gas and the other was set for dead volume. The syringe needles were inserted into the septum about halfway into the vial. Nitrogen gas was injected while water was extracted to create an unpressurized headspace of $8 \mathrm{~mL}$ and a water sample of $12 \mathrm{~mL}$. The samples were then shaken vigorously and refrigerated overnight to allow the gases to equilibrate between the headspace and liquid phases. They were then allowed to warm to room temperature $\left(22^{\circ} \mathrm{C}\right)$ before analysis.

The SRI 8610C gas chromatograph (GC), with conductivity detector (TCD) and flame ionization detector (FID), has detection limits at $1 \mathrm{ppm}$. The GC was calibrated by injecting a $1 \%$ gas standard of $\mathrm{CH}_{4}, \mathrm{CO}_{2}$, and nitrogen into the direct injection valve. High-purity helium at $\sim 22 \mathrm{~mL} \mathrm{~min}^{-1}$ was used as a carrier gas. The oven was programmed with an initial temperature of $40^{\circ} \mathrm{C}$ for $1 \mathrm{~min}$, increased at $15^{\circ} \mathrm{C} \mathrm{min}-1$ to $100^{\circ} \mathrm{C}$, then held for $5 \mathrm{~min}$. To ensure vaporization of the sample, the injector and FID were set at $200^{\circ} \mathrm{C}$ and $250^{\circ} \mathrm{C}$, respectively. The FID hydrogen flow was set at $40 \mathrm{~mL} \mathrm{~min}^{-1}$, and the air flow was set at $400 \mathrm{~mL} \mathrm{~min}^{-1}$. PeakSimple software was used for signal acquisition and peak integration. Samples of $5 \mathrm{~mL}$ were obtained from water sample vials, and $2.5 \mathrm{~mL}$ samples were obtained from the gas sample vials via syringe. These samples were directly injected into the GC.

Calculations of Kampbell and Vandergrift (1998) were followed. Henry's law, the partial pressure of the gas, the temperature of the sample, the volume of the sample bottle, and the molecular weight of the gas were used in these calculations. Total concentration was measured in milligrams of gas per liter of water that was present in the original, $10 \mathrm{~mL}$, water sample.

\section{Results}

\subsection{Headspace gas samples}

The gas traps showed little to no water displacement and showed no measurable change between the collection days
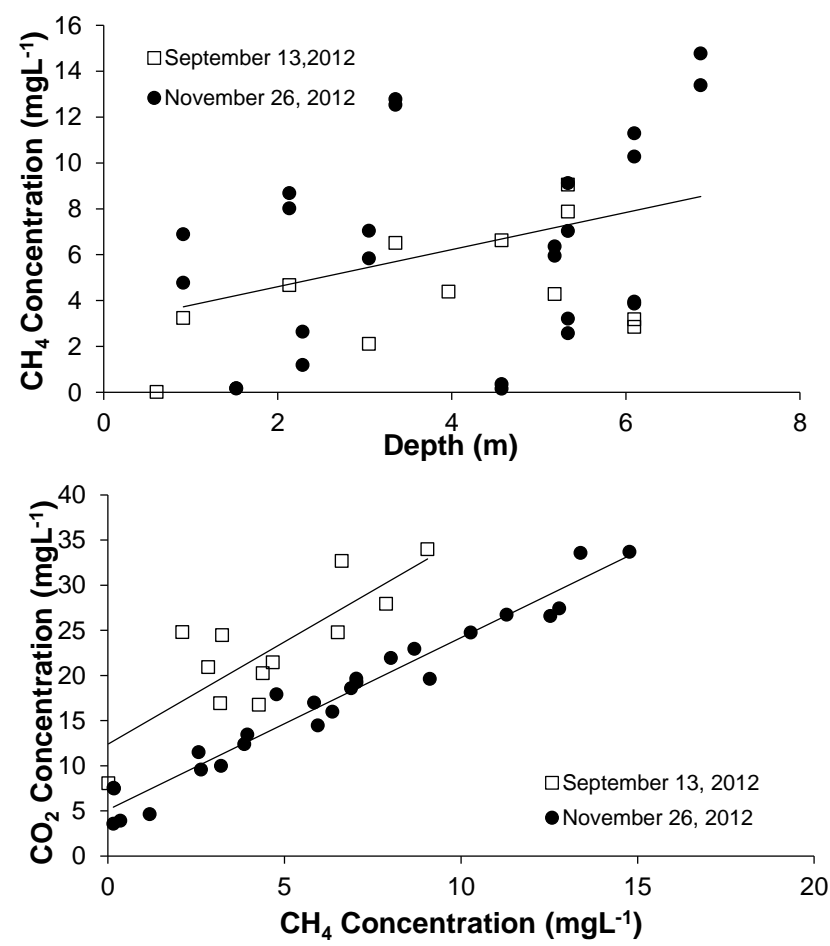

Fig. 4. Top: $\mathrm{CH}_{4}$ concentrations versus depth. A weak correlation was found between depth and $\mathrm{CH}_{4}$ concentrations $\left(R^{2}=0.134\right.$, $p=0.005)$. Bottom: $\mathrm{CH}_{4}$ concentrations increase with increasing $\mathrm{CO}_{2}$ concentrations for 13 September $\left(R^{2}=0.667, p=0.0008\right)$ and 26 November $2012\left(R^{2}=0.956, p=4.51493 \mathrm{E}-09\right)$.

spanning approximately $50 \mathrm{~h}$. In fact, no measurable change in water displacement was observed throughout the summer. Headspace gas samples in the two deepest piezometers $(6.5$ and $6.0 \mathrm{~m}$ ) contained $\mathrm{CH}_{4}$ concentrations ranging from 635 to $3369 \mathrm{ppm}$ over the two-day period. $\mathrm{CH}_{4}$ concentrations in piezometer headspace samples collected on 24 May 2012 were roughly half of those measured in samples collected in 22 May 2012, for the two deepest wells. GC analysis of gas samples from the three shallower wells $(4.5,3.0$, and $2.0 \mathrm{~m})$ showed no detectable $\mathrm{CH}_{4}$ concentrations for either of the two collection days.

\subsection{Water samples}

Dissolved $\mathrm{CH}_{4}$ concentrations from the two sample days ranged from 0.01 to $14.77 \mathrm{mg} \mathrm{L}^{-1}$ (mean $(\mu)=5.73 \mathrm{mg} \mathrm{L}^{-1}$, standard deviation $(\sigma)=3.92 \mathrm{mg} \mathrm{L}^{-1}$ ) (Fig. 4). Average concentrations of $\mathrm{CH}_{4}$ for 13 September 2012 and 26 November 2012 are 4.57 and $6.27 \mathrm{mg} \mathrm{L}^{-1}$, respectively. Average $\mathrm{CH}_{4}$ concentrations for the shrub site, pools and esker site, and wooded heath and upland site are 5.22, 6.12, and $5.70 \mathrm{mg} \mathrm{L}^{-1}$, respectively. Average $\mathrm{CH}_{4}$ concentrations at the pools and esker site increased from $3.75 \mathrm{mg} \mathrm{L}^{-1}$ on 13 September to $7.50 \mathrm{mg} \mathrm{L}^{-1}$ on 26 November. Air temperatures over this time period decreased from a high of 


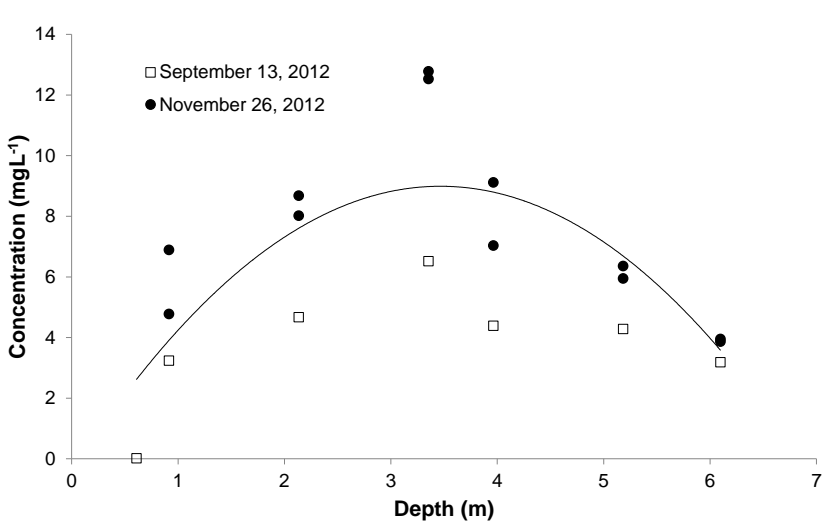

Fig. 5. $\mathrm{CH}_{4}$ concentrations at the pools and esker site (ii). Data showed the highest average concentrations of $\mathrm{CH}_{4}$ from all 4 sites. Data from 13 September and 26 November 2012 shows higher concentrations at the approximate depth of the esker crest $(\sim 3 \mathrm{~m})$, indicating increased $\mathrm{CH}_{4}$ production at depth and possible hot spot production due to esker influence. The quadratic regression line shown is significant $\left(R^{2}=0.47, p=0.002\right)$.

$11^{\circ} \mathrm{C}$ to a high of $1{ }^{\circ} \mathrm{C}$. Comparison of $\mathrm{CH}_{4}$ concentration and depth showed a significant, but weak, correlation $\left(R^{2}=0.1342, p=0.005\right)$ (Fig. 4). Saturation of $\mathrm{CH}_{4}$ in water at $1 \mathrm{~atm}$ and room temperature is $22.7 \mathrm{mg} \mathrm{L}^{-1}$ (Wiesenburg and Guinasso, 1979). No samples were supersaturated with respect to $\mathrm{CH}_{4}$. Peat pore water $\mathrm{CH}_{4}$ concentrations at the pools and esker site peak at a depth of $3.5 \mathrm{~m}$, are higher at depths of 2 to $4 \mathrm{~m}$ compared to other sites, and have a weak quadratic trend with depth $\left(R^{2}=0.474, p=0.002\right)$ (Fig. 5). The highest concentrations of $\mathrm{CH}_{4}$ at all wells were found at depths greater than $2 \mathrm{~m}$. Samples collected from the shrub site at a depth of $4.5 \mathrm{~m}$ contained anomalously low $\mathrm{CH}_{4}$ concentrations just $2 \mathrm{~m}$ above the highest concentration found in the study.

$\mathrm{CO}_{2}$ concentrations ranged from 3.5 to $34.0 \mathrm{mg} \mathrm{L}^{-1}$ $(\mu=18.87, \sigma=8.39)$. Unlike $\mathrm{CH}_{4}$, average $\mathrm{CO}_{2}$ decreased from $22.75 \mathrm{mg} \mathrm{L}^{-1}$ on 13 September 2012 to $17.08 \mathrm{mg} \mathrm{L}^{-1}$ on 26 November 2012. Highest concentrations of $\mathrm{CO}_{2}$ were found at $6 \mathrm{~m}$. No samples were supersaturated $\left(1.45 \mathrm{~g} \mathrm{~L}^{-1}\right.$ at standard pressure and $20^{\circ} \mathrm{C}$; Wiesenburg and Guinasso, 1979) with respect to $\mathrm{CO}_{2}$. There is a strong linear correlation between $\mathrm{CO}_{2}$ and $\mathrm{CH}_{4}$ for 13 September $\left(R^{2}=0.667, p=0.0008\right)$ and 26 November 2012 $\left(R^{2}=0.956, p=4.51493 \times 10^{-9}\right)($ Fig. 4$)$, possibly a result of $\mathrm{CO}_{2}$ and $\mathrm{CH}_{4}$ being produced in equal parts by acetate splitting.

\subsection{Pressure data}

Daily fluctuations in hydraulic head data match the patterns attributed to evapotranspiration in wetland systems (Mitsch and Gosselink, 2007) due the nighttime recovery of water levels and because fluctuations only occurred during the growing season. Hydraulic head data also contained unusual

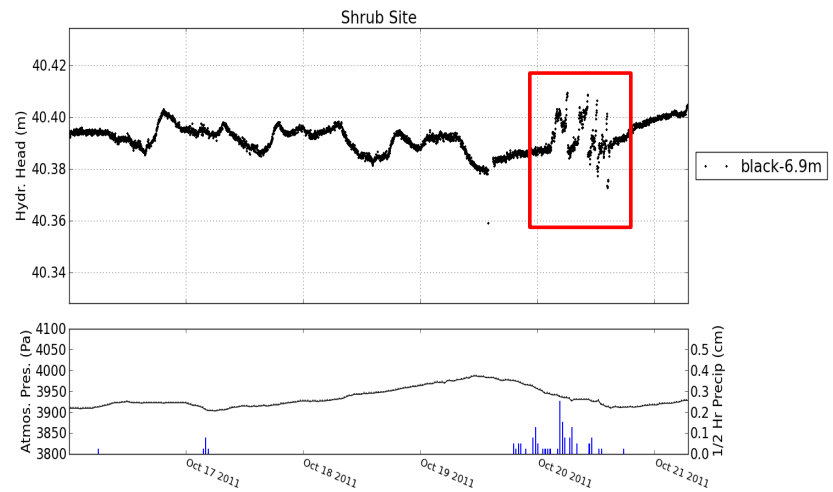

Fig. 6. Plot highlighting fluctuations in hydraulic head from the $6.9 \mathrm{~m}$ well at the shrub site (i). Fluctuations believed to be an ebullition event are outlined by the red box. Daily fluctuations in hydraulic head are believed to be caused by evapotranspiration. Low reading of $40.36 \mathrm{~m}$ was recorded when the logger was pulled to download data.

fluctuations lasting 2 to $24 \mathrm{~h}$ associated with anomalous subsurface pressure changes (Fig. 6). Visual inspection of the hydraulic head data indicates these fluctuations are larger than the daily evapotranspiration signal, and these fluctuations did not occur when the sites were visited to conduct field work. These unusual fluctuations occur as 2 to $5 \mathrm{~cm}$ spikes in hydraulic head data that occur during decreasing atmospheric pressure and are accompanied by a rising water level due to precipitation (Fig. 7). A total of 48 events were recorded from August 2011 to December 2012. The shrub site (i) recorded a total of 9 events, with 7 events occurring in the fall of these two years. The most events were recorded at the pools and esker site (ii) with 15 events occurring from August through December 2011, 4 occurring from January through May 2012, and 4 events occurring from June through November 2012. At the upland site (iii), 12 events were recorded from August through December 2011 and 4 events occurred from June through December 2012.

Unusual fluctuations in hydraulic head were interpreted as FPG movement and release within the peat column (Fig. 6). Hydraulic head typically increases rapidly with increased hydraulic heads lasting a few hours, followed by a sharp decrease in hydraulic head, and finally a recovery of hydraulic head back to levels consistent with long-term data. This pattern may occur several times over longer-duration events, and these events end when lowest atmospheric pressure is reached and precipitation ends. These events are recorded more frequently by wells screened more than $3 \mathrm{~m}$ below the peat surface. Asynchronous hydraulic head fluctuations (different times and durations) were recorded at different depths in well clusters (Fig. 7). Fluctuations in wells just a few feet apart will start up to an hour apart and have duration differences of up to a few hours. Fluctuations amplitudes also differ within well clusters during the same event, with measurements of 5 and $1 \mathrm{~cm}$ pressure fluctuations occurring in 


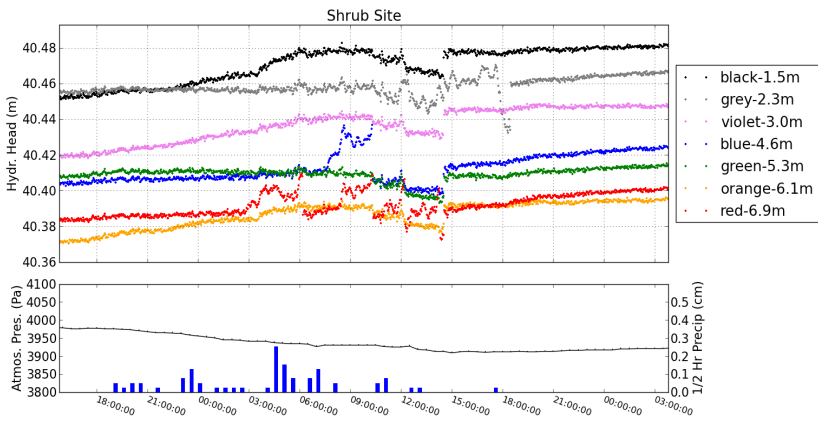

Fig. 7. Fluctuations in hydraulic head at the shrub site (i) on 20 October 2011, believed to be ebullition events occurring during a strong drop in atmospheric pressure and a low-precipitation event. The pressure release lasts for different lengths of time at different depths of peat. The pressure fluctuations move upward in the peat column at 07:00 EDT.

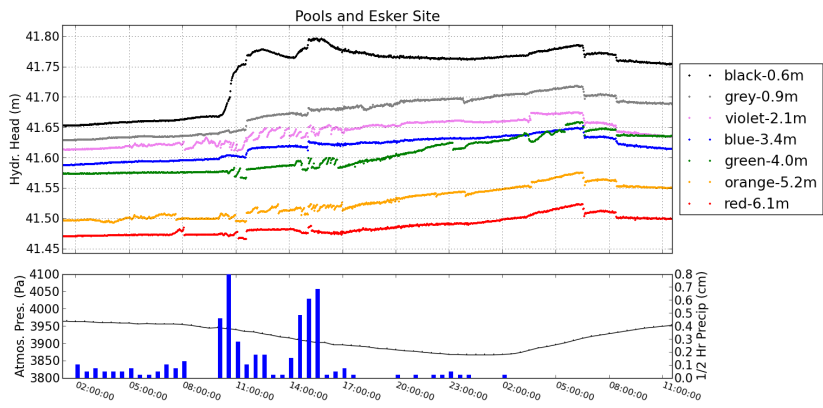

Fig. 8. Pressure transducer data during the initial atmospheric pressure drop during Tropical Storm Irene on 28 August 2011. Fluctuations in pressure data believed to be gas release occur in all loggers. A downward gradient in hydraulic head towards the esker is also evident.

neighboring wells. In Fig. 7, the fluctuations at 07:00 EDT move upward in the peat column, suggesting upward migration of FPG.

Hurricane Irene, a weak tropical storm when it passed over Maine, brought one of the largest pressure drops to the study area in August 2011. During this event, hydraulic head fluctuations were recorded at the two sites instrumented at the time. This event occurred just before the lowest storm pressure and also during a rise in water table due to high rainfall rates of up to $1.6 \mathrm{~cm} \mathrm{~h}^{-1}$ (Fig. 8). The water level data fluctuations start at different times in neighboring wells and have durations of up to $24 \mathrm{~h}$. The fluctuations in the 2,5 , and $6 \mathrm{~m}$ wells begin before the high rainfall rates that coincide with fluctuations in the other loggers.

The data loggers also measured temperature data. These data reveal a temperature inversion that occurs in the late fall as seen in another peatland study (e.g., McKenzie et al., 2007) (Fig. 9). At $1 \mathrm{~m}$ depth, the temperature fluctuates between 3.7 and $13.8^{\circ} \mathrm{C}$, peaking in September, while

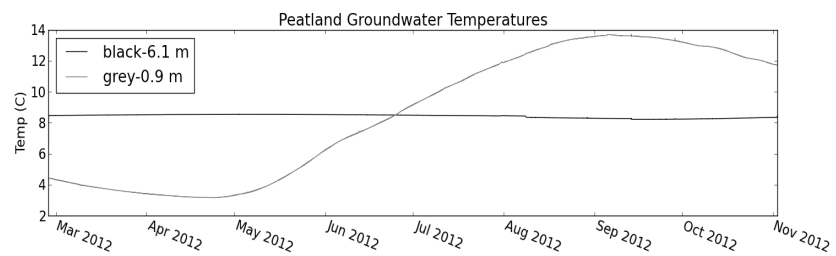

Fig. 9. Temperature data from 0.9 and $6.1 \mathrm{~m}$ monitoring wells equipped with pressure transducers. Temperatures were constant in deep peat allowing for constant $\mathrm{CH}_{4}$ production.

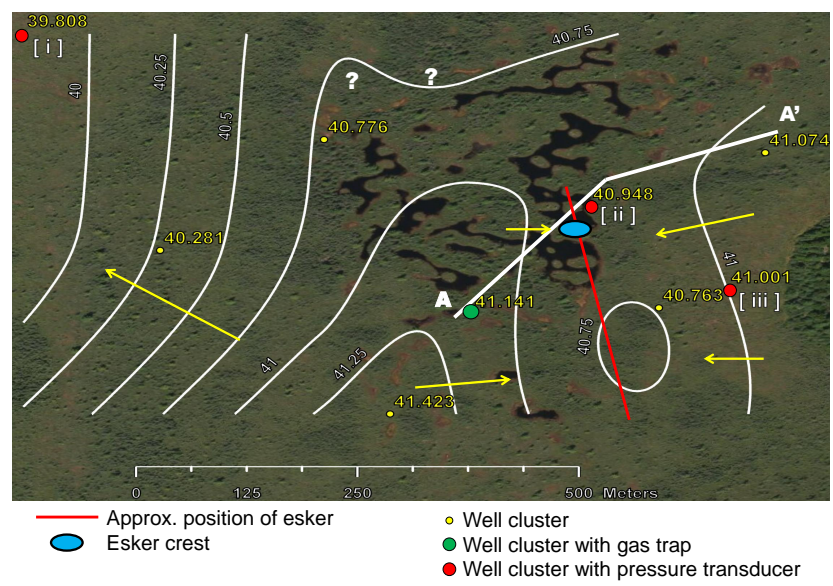

Fig. 10. Central unit enlarged showing the positions of 9 well clusters and the relative position of the esker and esker crest (Comas et al., 2011). Groundwater flow in the central unit is based off water level readings from $3 \mathrm{~m}$ wells on 5 November 2011. White line, $\mathrm{A}-\mathrm{A}^{\prime}$, refers to cross sections in Fig. 11. There is an area of lower hydraulic head above the esker driving convergent flow.

the deeper peat has a relatively constant temperature ranging from 8.2 to $8.6^{\circ} \mathrm{C}$, peaking in May.

\subsection{Esker influence}

Potentiometric surfaces and cross sections, illustrating the hydraulic head distribution and inferred groundwater flow patterns, were created from seasonal water level measurements. Flow regimes are consistent throughout the year, with less than a half meter of variability in water levels. Flow direction for the peatland runs east to west towards Pushaw Lake. This general flow pattern is disrupted by an area of lower hydraulic head that exists above the position of the esker at the eastern edge of the pool system (Fig. 10). Convergent and downward flow (Fig. 11) occurs near the esker crest. The downward hydraulic gradients occur at all peat depths surrounding the esker crest except at the peat interface with the mineral soil, where low vertical hydraulic gradients suggest horizontal flow is the dominant flow component. 


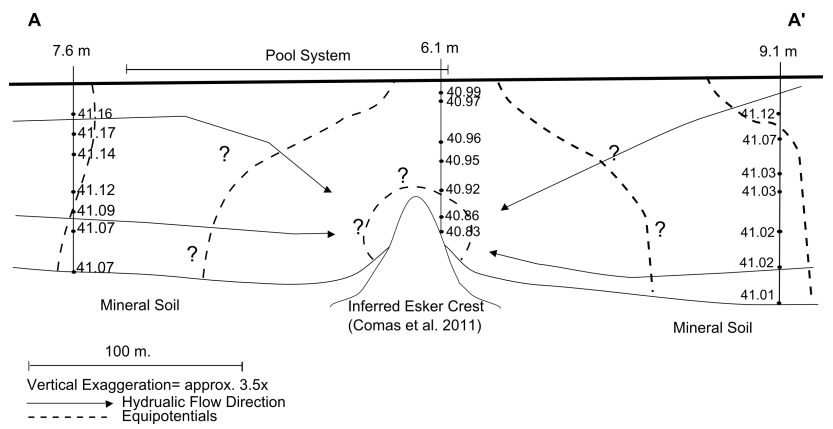

Fig. 11. Cross section A-A' from Fig. 9 on 5 November 2011. The esker crest is driving down flow that may drive a downward transport of labile carbon to deeper peat and increase FPG production.

\section{Discussion}

\subsection{Gas and water samples}

Gas samples from headspace in gas traps showed little to no indication of FPG release. Headspace in deep wells fitted with gas traps contained up to $3300 \mathrm{ppm} \mathrm{CH}_{4}$, but showed no displacement, indicating $\mathrm{CH}_{4}$ concentrations in wells are derived from diffusion, while shallow to medium wells showed no detectable concentrations of $\mathrm{CH}_{4}$. Although FPG may be released during initial installation of monitoring wells, the installation of monitoring wells at this study site has little to no effect on long-term gas pressure regimes in the peatland subsurface and does not allow FPG trapped in peat pore spaces to escape. Wells designed with thin horizontal machine slots $(0.5 \mathrm{~mm})$ will limit bubble migration in wells, while openended tubes or coarse screens could allow for more FPG escape from peat. Proper well design is crucial when monitoring hydrology and FPG in peatlands.

Other studies have reported as much as $40 \%$ of their samples supersaturated with $\mathrm{CH}_{4}$ (Romanowicz et al., 1995). Although none of our tested water samples were supersaturated with respect to $\mathrm{CH}_{4}$ or $\mathrm{CO}_{2}$, bubbles were seen forming in some capped $10 \mathrm{~mL}$ glass vials soon after collection. Some degassing of samples may have been possible upon collection when samples were transferred from the Erlenmeyer flask to the $10 \mathrm{~mL}$ glass vials, although samples were carefully transferred. The shallow peat model would suggest a constant or gradually decreasing $\mathrm{CH}_{4}$ with depth due to higher summer temperatures and a higher supply of labile carbon in shallow peat. This gradual decrease in $\mathrm{CH}_{4}$ concentrations was not measured in samples collected at Caribou Bog. Higher concentrations were found in peat depths below $2 \mathrm{~m}$ than those in shallow peat, and the highest $\mathrm{CH}_{4}$ concentrations were found at the deepest monitoring well at $6.5 \mathrm{~m}$ depth. This suggests significant storage of $\mathrm{CH}_{4}$ at depths greater than $2 \mathrm{~m}$.

The production and storage at depth may be due to temperature inversions seen between shallow and deep peat in the fall when samples were taken (Fig. 9). Methanogenesis rates are dependent on temperature (Hanson and Hanson, 1996; Dedysh, 2002), and the higher deep peat temperatures may drive higher production rates at depth during colder months. This temperature inversion may also explain the low $\mathrm{CH}_{4}$ concentrations measured in the upper peat layers in early and late fall. $\mathrm{CH}_{4}$ production likely continues through the winter in the deeper peat, resulting in high $\mathrm{CH}_{4}$ concentrations (Dise, 1993; Tokida et al., 2007a), whereas $\mathrm{CH}_{4}$ production in the shallow peat layers will decrease or stop in the cold upper peat layers. It is also possible that the $\mathrm{CH}_{4}$ concentrations in upper peat are not elevated because FPG is mobilized easily and undergoes diffusion in upper peat near the vadose zone (Joabsson and Christensen, 2001; Glaser et al., 2004; Coulthard et al., 2009). The deeper FPG is not mobilized as easily and may go into and out of the gas phase during changes in atmospheric pressure. This phase change occurs in semi-confining layers and increases $\mathrm{CH}_{4}$ concentrations until a threshold is reached and an ebullition event occurs (Glaser et al., 2004).

Unlike $\mathrm{CH}_{4}$, a decrease in average $\mathrm{CO}_{2}$ concentration was measured between 13 September and 26 November 2012. Similar to $\mathrm{CH}_{4}, \mathrm{CO}_{2}$ concentrations were undersaturated in all samples. As $\mathrm{CH}_{4}$ concentrations in samples increase, so do $\mathrm{CO}_{2}$ concentrations. The linear relationship between $\mathrm{CO}_{2}$ and $\mathrm{CH}_{4}$ could result from the breakdown of acetate by acetotrophic methanogens. This availability of $\mathrm{CO}_{2}$ at high concentrations, along with stable temperatures at depth, could make $\mathrm{CO}_{2}$ a source of year-round $\mathrm{CH}_{4}$ production. Reduction of $\mathrm{CO}_{2}$ by hydrogenotrophic methanogens, using $\mathrm{H}_{2}$ from fermentation of polysaccharides, is a favored pathway of $\mathrm{CH}_{4}$ at depth (Hornibrook et al., 1997). These two pathways of $\mathrm{CH}_{4}$ production result from fermentation of labile carbon and could be enhanced with a higher availability of labile carbon.

The samples from the pools and esker site (ii) showed the highest average $\mathrm{CH}_{4}$ concentrations for both sampling days. This suggests that the area may have enhanced $\mathrm{CH}_{4}$ production due to convergent flow toward the high permeability esker crest that underlies the peat surface by $3 \mathrm{~m}$, less than $15 \mathrm{~m}$ from the well cluster (Comas et al., 2011). Increased $\mathrm{CH}_{4}$ concentrations were found at depths from 1.5 to $4 \mathrm{~m}$ when compared to other well clusters (Fig. 5). The $\mathrm{CH}_{4}$ concentrations decrease away from the $3 \mathrm{~m}$ sample depth, suggesting enhanced $\mathrm{CH}_{4}$ production rates at the approximate depth of the esker crest. This may be due to downward flow in this area of convergence that causes a downward transport of labile carbon to the depth of the esker crest, driving higher rates of methanogenesis.

\subsection{Hydrologic data}

Water level measurements and pressure transducer data from the pools and esker site (ii) indicate that the esker is acting as a highly permeable pathway for water flow out of the peatland. General flow patterns (Fig. 10) are not significantly 
impacted by error in hydraulic head data related to the accuracy of GPS measurements $( \pm 5 \mathrm{~cm})$. Errors in vertical head differences are much smaller $( \pm 0.5 \mathrm{~cm})$ and are related to measurement of water levels below the top of the wells and using a carpenter level to define a horizontal surface between the wells. The esker and associated convergent flow, not a break in slope found by Lowry et al. (2009), is responsible for the location of the pool system in Caribou Bog. As mentioned before, higher concentrations of dissolved $\mathrm{CH}_{4}$ were measured at the approximate depth of the esker crest, suggesting that the methanogenesis rates are higher in the vicinity of the esker crest. Younger radiocarbon dates of dissolved organic carbon in deep peat indicate downward transport of labile carbon in other studies (Aravena et al., 1993; Charman et al., 1994; Chanton et al., 1995; Chasar et al., 2000). Computer simulations have also shown permeable mineral lenses to create a downward transport effect in peatlands (e.g., Reeve et al., 2009). Since the shallow peat pore waters above the esker did not contain high $\mathrm{CH}_{4}$ concentrations, it seems likely that the increased dissolved gas concentrations were due to production of $\mathrm{CH}_{4}$ at depth resulting from the convergent flow paths carrying substrate for $\mathrm{CH}_{4}$ production. These data support the hypothesized relationship between the hydrualics and FPG processes that exist in northern peatlands.

Fluctuations in hydraulic head during decreasing atmospheric pressure and a rising water table have been interpreted as $\mathrm{CH}_{4}$ ebullition events lasting 2-24h. These 2 to $5 \mathrm{~cm}$ hydraulic head fluctuations gradually increase, followed by sharp decreases and then a return to hydraulic head consistent with long-term data. This cycle may repeat several times depending on the scale of the event. The fluctuations are initiated in the deeper wells and propagate up the peat column, suggesting upward migration of gas or progressive formation of bubbles from deep pore water with higher dissolved gas concentrations to shallower peat pore water. Hydraulic head fluctuations occur much more frequently in the fall during the study period. In the fall of the first year, events were recorded almost weekly, while only monthly events occurred during the rest of the year. This could be due to a combination of buildup of gas concentrations through the summer months that is released in the fall and a higher frequency of strong storm events and reduced plant-mediated transport in the fall months. Fluctuations were more numerous from the pools and esker site (ii), again suggesting higher methanogenesis rates at this site.

Lowering atmospheric pressure and gas release are linked in freshwater lake environments (Mattson and Likens, 1990; Casper et al., 2000; Engle and Melack, 2000) and in peatlands (Rosenberry et al., 2003; Glaser et al., 2004; Strack et al., 2005; Tokida et al., 2007b; Comas et al., 2008). A relationship between lowering atmospheric pressure and gas release in the vicinity of data loggers was also seen in this study. Fluctuations are measured with pressure transducers during periods of lowering atmospheric pressure and end

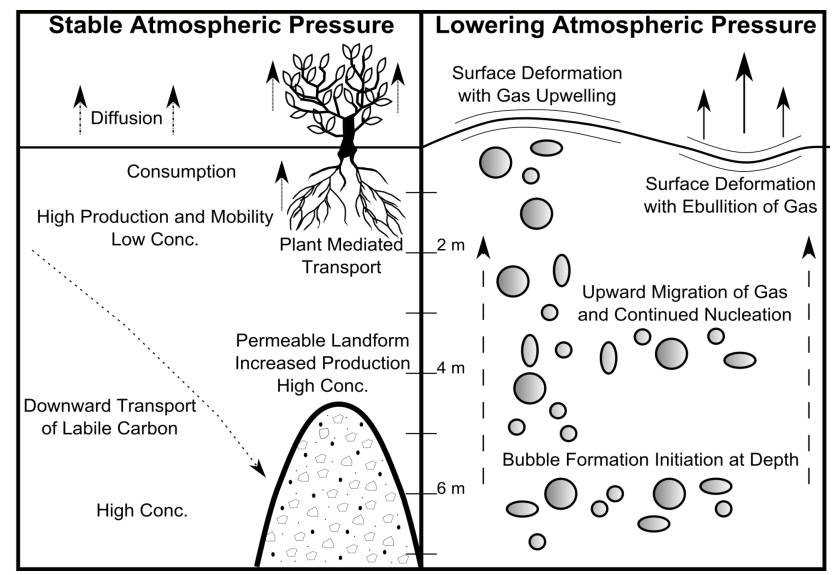

Fig. 12. Conceptual model showing gas production during stable atmospheric pressure and ebullition of FPG during a decrease in atmospheric pressure.

when the lowest atmospheric pressure is reached. Decreases in atmospheric pressure are also accompanied by rising water levels due to precipitation, and fluctuations may begin before the strongest precipitation occurs. Fluctuations do not occur during high-precipitation events that show little atmospheric pressure change but do occur during events with large pressure changes and little rainfall. The largest drops in atmospheric pressure were accompanied by signals in all data loggers lasting until atmospheric pressure began to increase. This suggests that lowering atmospheric pressure, rather than precipitation and associated rising water table position, is the dominant driver of FPG mobilization.

Atmospheric temperature changes did not coincide with fluctuations seen in pressure transducer data. We do not believe temperature to be a driver of FPG release from deep peat because temperatures below the first $2 \mathrm{~m}$ of peat are relatively constant around $8^{\circ} \mathrm{C}$. The constant temperatures could be driving year-round $\mathrm{CH}_{4}$ production in deep peat. Four fluctuation events were found at the pools and esker site (ii) from January to May 2012, demonstrating the ability of FPG to migrate in the subsurface in winter and spring. Snowpack was lost several times during the winter and it is possible that this allowed gas release to the atmosphere. Pools, which were unfrozen for much of the winter, may act as a pathway for release. Other studies have found $\mathrm{CH}_{4}$ release with winter ice breakup (Dise, 1993) and as large spring releases (Tokida et al., 2007a). Tokida et al. (2007) showed large amounts of gas release from a peatland after spring snow and ice melt, which could be attributed to gas buildup due to winter production. Winter FPG buildup was also shown in a GPR study at Caribou Bog (Comas et al., 2007) where the constant deep peat temperatures could be driving year-round production and release.

Ebullition events may be caused by the transfer of dissolved $\mathrm{CH}_{4}$ under large partial pressures, triggered by drops 
in atmospheric pressure, into FPG (e.g., Kellner et al., 2006) (Fig. 12). Undersaturated $\mathrm{CH}_{4}$ concentrations measured in pore water samples represent average concentrations over a large volume of peat and may not capture small regions within the peat containing high $\mathrm{CH}_{4}$ concentrations (e.g., Baird et al., 2004) that act as hot spots for bubble formation. Higher dissolved gas concentrations would reduce the atmospheric pressure decrease needed for nucleation of FPG and vice versa. Nucleation of FPG may occur more readily in the catotelm where, unlike the acrotelm, dissolved gas is not undergoing the high rates of diffusion and plant-mediated transport that decrease dissolved gas concentrations (Fig. 12). Thus, the catotelm will contain partial pressures of dissolved gases that are higher than those in the acrotelm. This may be causing the variable event lengths and initiation times of gas release at different depths seen in the pressure transducer profiles. This gas would move upward in the peat column and release to the atmosphere in an ebullition event. Once ebullition occurs, it continues until the difference in atmospheric pressure and partial pressures of dissolved gasses can no longer sustain bubble growth. During the ebullition event there would be volume changes below the peat surface that could cause surface deformations as seen in a growing number of studies (Glaser et al., 2004; Comas et al., 2008). It is possible that the volume changes of FPG in the subsurface are causing the fluctuations seen in the pressure transducer data. As the bubbles nucleate and grow, the volume of gas would increase hydraulic head readings. These readings would suddenly decrease as an ebullition event occurs and then return to normal readings when the ebullition event ends. This process would likely go on if the dissolved gas concentrations were high enough or the atmospheric pressure continued to drop, thereby initiating further bubble formation. The termination of an ebullition event would be caused by either an increase in atmospheric pressure or a substantial decrease in dissolved gas concentrations in peat pore water.

\section{Conclusions}

Our gas traps indicate that the installation of wells does not affect long-term gas concentrations or create conduits for gas escape after well installation and development. $\mathrm{CH}_{4}$ concentrations in monitoring well water samples confirm that there is substantial storage and production of $\mathrm{CH}_{4}$ at depths greater than $2 \mathrm{~m}$. This $\mathrm{CH}_{4}$ at depth is transferred from dissolved to gas phases, likely through nucleation and membranes of bubbles. This occurs until a threshold is reached and an ebullition event is triggered by lowering atmospheric pressure, as seen in our data-logging pressure transducer data, and may continue until the difference between pressures of the atmosphere and dissolved gas can no longer sustain release. Hydraulic head fluctuations measured with data-logging pressure transducers are a potential tool for monitoring gas release. It appears likely that a connection exists between hydrogeologic conditions and FPG production, storage, and release. These connections and $\mathrm{CH}_{4}$ in the catotelm are of paramount importance and should be studied further to assess the true impact of northern peatlands in the global carbon cycle.

Acknowledgements. We thank C. Wheeler and S. Beis for training and use of their gas chromatograph. We also thank K. Schäfer for her expertise and Z. Yu for analyzing gas samples from gas traps. We thank M. Yates for the use of Department of Earth and Climate Science weather data. We thank C. Westervelt and R. Perkins for assistance installing monitoring wells and C. Steiner for assistance collecting water samples. Finally, we thank the anonymous reviewers for their valuable comments and suggestions to improve the quality of the paper. This research was funded by the National Science Foundation under grant EAR1044979.

Edited by: P. Grathwohl

\section{References}

Aravena, R., Warner, B. G., Charman, D. J., Belyea, L. R., Mathur, S. P., and Dinel, H.: Carbon isotopic composition of deep carbon gases in an ombrogenous peatland, northwestern Ontario, Canada, Radiocarbon (United States), 35, available at: http://www.osti.gov/energycitations/product.biblio.jsp? osti_id=6294284 (last access: 7 March 2013), 1993.

Baird, A. J. and Waldron, S.: Shallow horizontal groundwater flow in peatlands is reduced by bacteriogenic gas production, Geophys. Res. Lett., 30, 20, doi:10.1029/2003GL018233, 2003.

Baird, A. J., Beckwith, C. W., Waldron, S., and Waddington, J. M.: Ebullition of methane-containing gas bubbles from near-surface Sphagnum peat, Geophys. Res. Lett., 31, 21, doi:10.1029/2004GL021157, 2004.

Borns, H. W.: Preliminary report on the age and distribution of the late Pleistocene ice in north central Maine, Am. J. Sci., 261, 738740, doi:10.2475/ajs.261.8.738, 1963.

Casper, P., Maberly, S. C., Hall, G. H., and Finlay, B. J.: Fluxes of Methane and Carbon Dioxide from a Small Productive Lake to the Atmosphere, Biogeochemistry, 49, 1-19, 2000.

Chanton, J. and Whiting, G.: Methane stable isotopic distributions as indicators of gas transport mechanisms in emergent aquatic plants, Aqua. Botan., 54, 227-236, doi:10.1016/03043770(96)01047-9, 1996.

Chanton, J. P., Bauer, J. E., Glaser, P. A., Siegel, D. I., Kelley, C. A., Tyler, S. C., Romanowicz, E. H., and Lazrus, A.: Radiocarbon evidence for the substrates supporting methane formation within northern Minnesota peatlands, Geochim. Cosmochim. Acta, 59, 3663-3668, doi:10.1016/0016-7037(95)00240-Z, 1995.

Charman, D. J., Aravena, R., and Warner, B. G.: Carbon dynamics in a forested peatland in north-eastern Ontario, Canada, J. Ecol., 82, 55-62, 1994. 
Chasar, L. S., Chanton, J. P., Glaser, P. H., Siegel, D. I., and Rivers, J. S.: Radiocarbon and stable carbon isotopic evidence for transport and transformation of dissolved organic carbon, dissolved inorganic carbon, and $\mathrm{CH}_{4}$ in a northern Minnesota peatland, Global Biogeochem. Cy., 14, 1095-1108, doi:10.1029/1999GB001221, 2000.

Comas, X., Slater, L., and Reeve, A.: Geophysical evidence for peat basin morphology and stratigraphic controls on vegetation observed in a Northern Peatland, J. Hydrol., 295, 173-184, doi:10.1016/j.jhydrol.2004.03.008, 2004.

Comas, X., Slater, L., and Reeve, A.: In situ monitoring of freephase gas accumulation and release in peatlands using ground penetrating radar (GPR), Geophys. Res. Lett., 34, L06402, doi:10.1029/2006GL029014, 2007.

Comas, X., Slater, L., and Reeve, A.: Seasonal geophysical monitoring of biogenic gases in a northern peatland: Implications for temporal and spatial variability in free phase gas production rates, J. Geophys. Res.-Biogeosci., 113, G01012, doi:10.1029/2007JG000575, 2008.

Comas, X., Slater, L., and Reeve, A. S.: Pool patterning in a northern peatland: Geophysical evidence for the role of postglacial landforms, J. Hydrol., 399, 173-184, doi:10.1016/j.jhydrol.2010.12.031, 2011.

Conrad, R.: Contribution of hydrogen to methane production and control of hydrogen concentrations in methanogenic soils and sediments, FEMS Microbiol. Ecol., 28, 193-202, doi:10.1016/S0168-6496(98)00086-5, 1999.

Coulthard, T. J., Baird, A. J., Ramirez, J., and Waddington, J. M.: Methane dynamics in peat: Importance of shallow peats and a novel reduced-complexity approach for modeling ebullition, in: Geophysical Monograph Series, edited by: Baird, A. J., Belyea, L. R., Comas, X., Reeve, A. S., and Slater, L. D., Vol. 184, 173185, American Geophysical Union, Washington, D. C., 2009.

Davis, R. B. and Anderson, D. S.: A numerical method and supporting database for evaluation of Maine peatlands as candidate natural areas, University of Maine, Orono, 1999.

Davis, R. B. and Anderson, D. S.: Classification and Distribution of Freshwater Peatlands in Maine, Northeastern Natural., 8, 1-50, doi:10.2307/3858261, 2001.

Dedysh, S. N.: Methanotrophic Bacteria of Acidic Sphagnum Peat Bogs, Microbiology, 71, 638-650, doi:10.1023/A:1021467520274, 2002.

Dise, N. B.: Methane emission from Minnesota peatlands: Spatial and seasonal variability, Global Biogeochem. Cy., 7, 123-142, doi:10.1029/92GB02299, 1993.

Engle, D. and Melack, J. M.: Methane emissions from an Amazon floodplain lake: Enhanced release during episodic mixing and during falling water, Biogeochemistry, 51, 71-90, doi:10.1023/A:1006389124823, 2000.

Glaser, P. H., Wheeler, G. A., Gorham, E., and Wright, H. E.: The Patterned Mires of the Red Lake Peatland, Northern Minnesota: Vegetation, Water Chemistry and Landforms, J. Ecol., 69, 575599, 1981.

Glaser, P. H., Chanton, J. P., Morin, P., Rosenberry, D. O., Siegel, D. I., Ruud, O., Chasar, L. I., and Reeve, A. S.: Surface deformations as indicators of deep ebullition fluxes in a large northern peatland, Global Biogeochem. Cy., 18, GB1003, doi:10.1029/2003GB002069, 2004.
Gorham, E.: Northern Peatlands: Role in the Carbon Cycle and Probable Responses to Climatic Warming, Ecol. Applic., 1, 182195, 1991.

Hanson, R. S. and Hanson, T. E.: Methanotrophic bacteria, Microbiol. Rev., 60, 439-471, 1996.

Hornibrook, E. R. C., Longstaffe, F. J., and Fyfe, W. S.: Spatial distribution of microbial methane production pathways in temperate zone wetland soils: Stable carbon and hydrogen isotope evidence, Geochim. Cosmochim. Acta, 61, 745-753, doi:10.1016/S0016-7037(96)00368-7, 1997.

Joabsson, A. and Christensen, T. R.: Methane emissions from wetlands and their relationship with vascular plants: an Arctic example, Global Change Biol., 7, 919-932, doi:10.1046/j.13541013.2001.00044.x, 2001.

Kampbell, D. H. and Vandegrift, S. A.: Analysis of Dissolved Methane, Ethane, and Ethylene in Ground Water by a Standard Gas Chromatographic Technique, J. Chromatogr. Sci., 36, 253256, doi:10.1093/chromsci/36.5.253, 1998.

Kellner, E., Baird, A. J., Oosterwoud, M., Harrison, K., and Waddington, J. M.: Effect of temperature and atmospheric pressure on methane $\left(\mathrm{CH}_{4}\right)$ ebullition from near-surface peats, Geophys. Res. Lett., 33, L18405, doi:10.1029/2006GL027509, 2006.

Khalil, M. A. K.: Atmospheric Methane: Its Role in the Global Environment, Springer-Verlag, New York, 2000.

Lai, D. Y. F.: Methane Dynamics in Northern Peatlands: A Review, Pedosphere, 19, 409-421, doi:10.1016/S1002-0160(09)00003-4, 2009.

Lowry, C. S., Fratta, D., and Anderson, M. P.: Ground penetrating radar and spring formation in a groundwater dominated peat wetland, J. Hydrol., 373, 68-79, doi:10.1016/j.jhydrol.2009.04.023, 2009.

Mattson, M. D. and Likens, G. E.: Air pressure and methane fluxes, Nature, 347, 718-719, doi:10.1038/347718b0, 1990.

McKenzie, J. M., Siegel, D. I., Rosenberry, D. O., Glaser, P. H., and Voss, C. I.: Heat transport in the Red Lake Bog, Glacial Lake Agassiz Peatlands, Hydrol. Process., 21, 369-378, doi:10.1002/hyp.6239, 2007.

Mitsch, W. J. and Gosselink, J. G.: Wetlands, Wiley, Hoboken, N.J., 2007.

Parsekian, A. D., Slater, L., Comas, X., and Glaser, P. H.: Variations in free-phase gases in peat landforms determined by groundpenetrating radar, J. Geophys. Res.-Biogeosci., 115, G02002, doi:10.1029/2009JG001086, 2010.

Reeve, A. S., Tyczka, Z. D., Comas, X., and Slater, L. D.: The influence of permeable mineral lenses on peatland hydrology, in: Geophysical Monograph Series, Vol. 184, edited by: Baird, A. J., Belyea, L. R., Comas, X., Reeve, A. S., and Slater, L. D., 289297, American Geophysical Union, Washington, D. C., 2009.

Romanowicz, E. A., Siegel, D. I., Chanton, J. P., and Glaser, P. H.: Temporal variations in dissolved methane deep in the Lake Agassiz Peatlands, Minnesota, Global Biogeochem. Cy., 9, 197-212, doi:10.1029/95GB00634, 1995.

Rosenberry, D. O., Glaser, P. H., Siegel, D. I., and Weeks, E. P.: Use of hydraulic head to estimate volumetric gas content and ebullition flux in northern peatlands, Water Resour. Res., 39, 1066, doi:10.1029/2002WR001377, 2003. 
Rydin, H., Jeglum, J., and Jeglum, J. K.: The biology of peatlands, Oxford university press, available at: http://www.cabdirect.org/ abstracts/20083000030.html (last access: 24 November 2012), 2006.

Siegel, D. I.: Ground water and the evolution of patterned mires, Glacial Lake Agassiz peatlands, northern Minnesota, J. Ecol., 71, 913-921, 1983.

Sjörs, H.: Bogs and Fens in the Hudson Bay Lowlands, Arctic, 12, 2-19, 1959.

Strack, M., Kellner, E., and Waddington, J. M.: Dynamics of biogenic gas bubbles in peat and their effects on peatland biogeochemistry, Global Biogeochem. Cy., 19, GB1003, doi:10.1029/2004GB002330, 2005.

Sundh, I., Nilsson, M., Granberg, G., and Svensson, B. H.: Depth Distribution of Microbial Production and Oxidation of Methane in Northern Boreal Peatlands, Microb. Ecol., 27, 253-265, doi:10.2307/4251351, 1994.

Tokida, T., Mizoguchi, M., Miyazaki, T., Kagemoto, A., Nagata, O., and Hatano, R.: Episodic release of methane bubbles from peatland during spring thaw, Chemosphere, 70, 165-171, doi:10.1016/j.chemosphere.2007.06.042, 2007a.
Tokida, T., Miyazaki, T., Mizoguchi, M., Nagata, O., Takakai, F., Kagemoto, A., and Hatano, R.: Falling atmospheric pressure as a trigger for methane ebullition from peatland, Global Biogeochem. Cy., 21, GB2003, doi:10.1029/2006GB002790, 2007b.

Waddington, J. M., Ketcheson, S. J., Kellner, E., Strack, M., and Baird, A. J.: Evidence that piezometers vent gas from peat soils and implications for pore-water pressure and hydraulic conductivity measurements, Hydrol. Process., 23, 1249-1254, doi:10.1002/hyp.7244, 2009.

Walter, B., Heimann, M., and Matthews, E.: Modeling modern methane emissions from natural wetlands. I- Model description and results, J. Geophys. Res.-Atmos., 106, 34189-34206, doi:10.1029/2001JD900165, 2001.

Whalen, S. C.: Biogeochemistry of Methane Exchange between Natural Wetlands and the Atmosphere, Environ. Eng. Sci., 22, 73-94, doi:10.1089/ees.2005.22.73, 2005.

Wiesenburg, D. A. and Guinasso, N. L.: Equilibrium solubilities of methane, carbon monoxide, and hydrogen in water and sea water, J. Chem. Eng. Data, 24, 356-360, doi:10.1021/je60083a006, 1979.

Wigley, T. M. L. and Schimel, D. S.: The Carbon Cycle, Cambridge University Press, 2000. 